University of Nebraska - Lincoln

DigitalCommons@University of Nebraska - Lincoln

Faculty Publications, UNL Libraries

Libraries at University of Nebraska-Lincoln

January 2007

\title{
ACADEMIC LIBRARIANS' VIEWS OF THE CHAIR'S PROFESSIONAL DEVELOPMENT ROLE
}

Dana W. R. Boden

University of Nebraska - Lincoln, dboden1@unl.edu

Follow this and additional works at: https://digitalcommons.unl.edu/libraryscience

Part of the Library and Information Science Commons

Boden, Dana W. R., "ACADEMIC LIBRARIANS' VIEWS OF THE CHAIR'S PROFESSIONAL DEVELOPMENT ROLE" (2007). Faculty Publications, UNL Libraries. 99.

https://digitalcommons.unl.edu/libraryscience/99

This Article is brought to you for free and open access by the Libraries at University of Nebraska-Lincoln at DigitalCommons@University of Nebraska - Lincoln. It has been accepted for inclusion in Faculty Publications, UNL Libraries by an authorized administrator of DigitalCommons@University of Nebraska - Lincoln. 


\author{
Dana W. R. Boden \\ University of Nebraska-Lincoln \\ Office phone: 402 472-4412
}

Fax: 402 472-7005

dboden@,unlnotes.unl.edu

Dana W. R. Boden is an Associate Professor, and has been a Subject Specialist Liaison Librarian at the University of Nebraska-Lincoln over 20 years. As liaison to five departments in the College of Agricultural Sciences and Natural Resources, as well as the Research and Extension Centers, her responsibilities include reference, collection development, and library instruction. She received her B.S. in Agriculture and M.A. in Education from Western Kentucky University; M.S.L.S. from the University of Kentucky; and Ph.D. in Educational Administration from the University of Nebraska-Lincoln. 


\section{ACADEMIC LIBRARIANS' VIEWS OF THE \\ CHAIR'S PROFESSIONAL DEVELOPMENT ROLE}

DANA W. R. BODEN

Published in E. D. Garten, D. E. Williams \& J. M. Nyce (Eds.), Advances in library administration and organization, vol. 24, (pp.117-149). Amsterdam:

Elsevier JAI. (Invited book chapter) 


\section{INTRODUCTION}

Academic librarians are well aware of the disparity within our ranks regarding our status. Our rank, status, title and standing within the institutions we serve vary. There is ongoing debate among ourselves regarding whether it is best to be in tenure-leading positions (Murray-Rust, 2005), or not burdened with the requirements (Carver, 2005). Individual views on the track academic librarians' careers should follow sometimes even change over time (Hill, 2005). Holding faculty status does not always mean the same thing from one institution to another (Cary, 2001). New hires are now given choices regarding their type of appointment at some institutions (Ruess, 2004). Even the Association of Research Libraries, in their annual survey, notes: "Since the criteria for determining professional status vary among libraries, there is no attempt to define the term "professional." Each library should report ... those staff members it considers professional(s)..." (Kyrillidou \& Young, 2005a \& 2005b).

"Professional academic librarians" were welcomed into membership in the American Association of University Professors (AAUP) in 1956. It was not until 1971 that the Association of College and Research Libraries membership officially approved Standards for Faculty Status for College and University Librarians (McAnally, 1975), with two revisions since (Krompart, 1994). The Standards address areas recognizable to any faculty member: professional responsibilities; governance (library, college, and university); compensation; 
tenure and promotion; sabbatical and other research leaves; research and development funds; and academic freedom (ACRL Committee on the Status of Academic Librarians, 2001).

Today, faculty status is still not a given for librarians in higher education. In fact, among the Carnegie research institutions just over half have faculty status for their librarians. The professional librarians at a large majority of the remaining institutions have what is termed academic status (Leysen \& Black, 1998; Lowry, 1993). The ACRL approved Guidelines for Academic Status for College and University Libraries in 1990. Included in the nine guidelines are recommendations for involvement in governance, research and professional activities, and protection of academic freedom (Kroll, 1994). Whether recognized with faculty or academic status, university librarians are expected to be involved in continuing professional development.

Still we are aware of our uniqueness among our university colleagues. Women account for almost twice the percentage of library faculty members at U.S. Association of Research Libraries University Libraries (63.85\%), (Kyrillidou \& Young, 2005a), as compared to the percentage of all faculty at doctoral-level institutions (33\%) (Curtis, 2004). A large majority of university library faculty positions require the Master of Library Science degree from an institution accredited by the American Library Association, thus most university library faculty share this disciplinary background (Lowry, 1993). Also, most of us came, 
and continue to come, through the program for the degree as non-traditional students, over 30 years of age (ALISE, 1991-2003). The disciplines represented by our other degree(s), however, are widely varied. Unlike teaching faculty in other departments across campus, we are usually employed on a twelve month basis. Yet, as with any tenure track position, participation in professional development activities is a requirement to meet the criteria for a successful bid for continuous appointment (tenure) and/or promotion (Leysen \& Black, 1998; Lowry, 1993). With our varied backgrounds, and life experiences, many come to librarianship having already been in the workforce and feel independent and confident in our own abilities.

The profession of librarianship is not focused simply in the academic realm, which likely contributes to the contradictory views of just what is and should be our role in the academy. Our colleagues in other types of libraries, while not focused on the requirements of obtaining tenure, and the myriad of activities that demands, share our commitment to service. The organization of many libraries, no matter the type, often means supervision and management of personnel, from students to volunteers to staff to fellow professionals, is required of many the librarian. Our focus on assisting our patrons in searching the literature has meant we are most comfortable reviewing the information available to us and synthesizing it for application to our situations. Yet much of the literature we look to for guidance and application is broad-based and widely- 
focused from the public, business world, rather than where our operations and career choice have actually placed us - on campus, in the academic setting, in professional library faculty positions.

\section{ROLE OF THE DEPARTMENT CHAIR IN FACULTY DEVELOPMENT}

The department chair position has long been recognized as an important one in post-secondary institutions (Heimler, 1967). For decades research has been focused on department chairs, their role and functions. A role in faculty development has been a constant for chairs; however, the types of activities and depth the role involved has evolved.

A review of the literature attests to faculty development continuing to be a concern of the academic community. Times of retrenchment and increasing numbers of mid-career faculty have brought times of reflection and increased research on effective faculty development. In the early literature faculty development was viewed almost exclusively in terms of how it could improve teaching (Group for Human Development in Higher Education, 1974; Bergquist \& Phillips, 1975). Also, it was commonly considered the responsibility of each individual faculty member, while the chair should assist and support their efforts (Gaff, 1975). In the mid-1980s Eble \& McKeachie's (1985) report on the Bush Foundation Faculty Development Project showed balance between faculty and administrative support was the key to successful faculty development and encouraged further research. 
The research has focused not only on the department chair's perceptions of their role, but from several levels: those of the chairs themselves (Creswell et al, 1990; Gmelch \& Miskin, 1993, 1995; Jennerich, 1981; Kremer-Hayon \& Aviitzhak, 1986; Lee, 1985; McLaughlin et al, 1975; Miles, 1983; Mitchell, 1986; Roach, 1976; Seagren et al, 1994; Smart, 1976; Wilhite, 1987); the faculty members' views (Daly \& Townsend, 1992, 1994; Gordon et al, 1991; Hirokawa et al, 1989; Knight \& Holen, 1985; Moses, 1985; Neumann \& Neumann, 1983; Watson, 1979, 1986); those of the chairperson's administrative supervisor -usually a dean (Jeffrey, 1985; Moxley \& Olson, 1990); and across all three levels ((Cohen et al, 1981; Falk, 1979; Jones \& Holdaway, 1995; Kenny, 1982; Leaming, 1998; Siever et al, 1972; Smith, 1972; Weinberg, 1984; Whitt, 1991). Many works cover the chairperson's entire responsibilities, but a recurrent theme presented in the literature has been the department chair's role in enhancing faculty development (Eble, 1990; Gmelch \& Miskin, 1995; Leaming, 1998; McKeachie, 1990; Seagren, Creswell, \& Wheeler, 1993; Tucker, 1992) or acting in a leadership role, which includes faculty professional development (Knight \& Trowler, 2001; Lucas \& Associates, 2000; McLaughlin et al., 1975). These works are chapters on the department chair's faculty development role, or monographs that address the overall role of the department chair, while including faculty development. There has also been research (Creswell \& Brown, 1992; Seagren, Wheeler, Mitchell, \& Creswell, 1986; Wilhite, 1990), literature review 
(Scott, 1990), and administrator opinion articles (Sorcinelli, 1990; Thompson, 1990; Wheeler, 1992) specifically addressing the chair's role in faculty development.

The faculty development role has sometimes been viewed as one activity, and sometimes multiple activities, in which a department chair may engage. The terms used for the role vary through the literature. Jennerich (1981) referred to the role as "leadership ability." "Leadership role" is the term used by McLaughlin et al. (1975). Smart (1976) and Hirokawa et al. (1989) use "faculty development." Moses (1985) refers to "encouragement" and Eble (1986) describes a role of chairs as "ingenious providers of motivation, support, and encouragement [for faculty]." Bland and Schmitz (1988, 1990a, 1990b) refer to a responsibility for taking on "faculty vitality", while Hecht et al. (1999) identified the role of a "purposeful, facilitative leader." Others perceived leadership as the overarching function of the chair, which takes into account all the skills, competencies, functions, roles, or activities undertaken to guide the department's way (Coats et al, 1996; Gordon et al., 1991; Mitchell, 1986).

Specific actions chairs may use in their role in faculty leadership or development have also been identified over the years. Some of these include: "place faculty on committees" (Weinberg, 1984); "encourages faculty to participate in conventions, conferences, professional associations, etc."; "reports departmental accomplishments to [the] dean or immediate supervisor" (Smith, 
1972); "commending achievement" (Moses, 1985); "delegates authority" (Kremer-Hayon and Avi-Itzhak, 1986); and "develop the potential of . . . junior faculty" (McLaughlin et al., 1975).

Creswell et al. (1990) identified three levels of faculty which may need assistance: newer faculty members need assistance toward successful tenure and promotion hearings; mid-career faculty members sometimes require assistance to maintain professional involvement; and senior faculty may need assistance to give new life to their careers. Some authors have addressed specific career stages of faculty professional development needs. Boice $(1992,2000)$ and Bensimon et al. (2000) focused on new faculty. Baldwin (1990) and Lucas \& Associates (2000) note differing requirements of faculty at various points throughout their professional life. An example is the need for "nurturing faculty vitality" of posttenure faculty (Licata, 2000).

Over the years the emphases have expanded and shifted with the times and interests on campuses, but the department chair continues to be viewed as a midlevel administrator in a position to act as a leader, encouraging or assisting faculty members, in professional development and growth. The literature has supported the premise that the chair's role in faculty development, and as a leader, can be influential in the life of a faculty member. The chair is situated strategically to assist faculty in their development, growth, and progress professionally. As the administrative middle manager the chair is naturally seen as in a leader position to 
influence subordinates. As the faculty member interacts with the chair of their department, roles are communicated and practices are observed. The faculty member's perceptions of the department chair's professional development role and leadership practices determine their professional relationship, which in turn can impact the career or, at least institutional, success of the faculty member.

\section{Department Chairs in Academic Libraries}

While research and literature exist on faculty perceptions of the chair's role in academic departments in various institution types across the United States and Canada, little research has addressed faculty perceptions of the department chair's role in non-teaching departments at the university level. The general literature on department chairs or faculty development almost never gives any indication that library personnel were considered, or included, in the research. Boice (1992) was a unique exception and also collaborated with librarians on research regarding library faculty and teaching faculty demands on scholarship (Boice et al, 1987). In his book on new faculty professional development he recognized the crucial role of department chairs in the success of faculty. He addressed the work to a broad audience, but chairs were listed as "first and foremost (p. xii)." He noticed libraries within the university setting include members who have faculty status, but do not teach courses on a regular basis, and observed faculty in other departments on campus may not even be aware if librarians have faculty status. His experience with researching new library faculty 
led him to remark that they, "more than any group ... suffered from unclear expectations" (Boice, 1992, p. 276).

Differences in the organizational setup of libraries may have delayed the focus of research from turning toward department chairs. Chief librarians at universities in the first half of the twentieth century tended to be quite autocratic, blocking the library from arranging itself along the lines of a more democratic organization similar to its teaching counterparts (McAnally, 1975). As a result, much of the research on leadership in academic libraries has been focused on the library deans or directors, not department chairs. At the same time, as has been observed, the need for support personnel to perform a myriad of duties in academic libraries has meant that librarians in their very first professional position may be called upon to be a supervisor of support staff or student workers (Bailey, 1976). The result has been literature focused on supervision of personnel and often based on a business management background. Specific department chair concerns, especially as related to leading faculty, have been addressed only in a limited manner. Excellent examples of this are the editions of Practical Help for New Supervisors prepared by the Supervisory Skills Committee, Personnel Administration Section, Library Administration and Management Association of the American Library Association (Giesecke 1992, 1997). Those, as well as several others (Evans \& Ward, 2003; Giesecke, 2001; Giesecke \& McNeil, 2005; Gordon, 2005; Pugh, 2005) take a broad approach, across types of libraries. 
While they provide helpful advice, and some focus is put on professionals and their development, three of the five are based on information and synthesis of previous literature (Giesecke; Giesecke \& McNeil; Pugh), another on the authors' "management experiences ... rooted in research" (Evans \& Ward, p. vii) and the last on unscientific web surveys of "self-described library managers" and library staff (Gordon).

Among those broad-based works that do focus on the academic library setting, the authors in Mech \& McCabe (1998) tend to view development as a part of leadership, with little actual text committed to how that occurs, or what is, or should be, involved. As the title states, Simmons-Welburn \& McNeil's (2004) work addresses human resource management, so again the needs specifically of professionals are not a major emphasis.

Even the literature regarding academic librarians at the department chair level varies on the title given their position. Examples are department chair, department head, division head, division chair, team leader, unit leader, middle manager, or supervisor.

Utilization of research instruments to determine library leadership or faculty development practices is limited. Such research specifically on department chairs in the academic library setting is an even smaller subset. Research on these library middle managers did not begin until the late 1960s (Bailey, 1987). Similar to the broader department chair literature, the main focus 
of the research and literature has been the chairs themselves or the views of higher administrators. The perceptions of faculty in university library departments regarding the department chair have not been well documented. Most publications regarding the subjects have been either based on data gathering that used a researcher-developed instrument, surveys of the existing literature, or were basically opinion pieces.

The predominance of library literature that focused on descriptions and applications with little actually of a research nature was noted by Plate (1970). He utilized a short questionnaire and interviews of middle managers in Association of Research Libraries (ARL) to find they felt professional development of those they supervised was not their responsibility, but the responsibility of the individuals themselves. Parallel to that finding, Stone (1969) surveyed "professional librarians" of which, approximately one half were in academic libraries, finding that while "the ultimate responsibility for continuing education was placed by the librarians on the individual (p.192)", the results urging administrator support for professional development included the observation "supervisors should be rewarded or promoted on the basis of how well they promote professional growth of those under them (p.175).”

Research on perceptions of middle managers and their superiors have included Bailey's $(1978,1981)$ interviews of middle managers and administrators in libraries of five ARL member institutions and Mitchell's (1989) survey of 
academic library department heads and their immediate supervisors in 137 academic libraries, using Fiedler's Contingency Model of Leadership Effectiveness.

Several studies regarding library leadership have used the Leadership Behavior Description Questionnaire - Form XII (LBDQ-XII), developed at Ohio State University, or a modified version. It examined the style of leadership as perceived by the supervisor and subordinate groups. The supervisor completed the instrument regarding them self, while a selected number of subordinates completed it regarding the supervisor. Research on libraries in institutions of higher education included Sparks (1976), Comes (1978), and Olive (1991). Sparks utilized the instrument for a very limited study of one academic library supervisor and fifteen subordinates. Comes targeted the directors at twenty-four institutions and eight subordinates who held supervisory responsibilities. Olive surveyed public services and technical services department heads, and their subordinates, both professional and non-professional, in private Liberal Arts I institution libraries.

Focusing research on the middle managers, Person (1980) used both questionnaires and interviews and included nine large academic libraries in the Great Lakes states in her research of managerial role concepts in academic and public libraries. Interestingly, the public library managers perceived themselves having higher levels of involvement in internally oriented roles such as "leader" 
than did their academic library counterparts, who gave higher ratings to their involvement in externally directed areas.

Bailey \& Murphy (1989) researched the "management competencies" of middle managers in eleven large ARL libraries in the Midwest, asking three managers with average performance records and three superior performers, at each institution, "to narrate three positive and three negative experiences in which they had utilized management principles." They then compared their findings to the academic portion of an earlier study. While the categories assigned differed between the two studies, they were similar and the results of both indicated an emphasis on staffing and personnel management, which included subcategories for motivation and staff development.

Heads of cataloging and heads of reference departments in over one hundred ARL libraries were surveyed by Wittenbach et al (1992) regarding management education and training. Their results showed few institutions required management training when hiring department chairs, or ongoing training for the chairs.

While looking at differences among the genders, Voelck (2003) interviewed "academic library middle managers", in Michigan. Regarding their self-described "management style" and utilization of thirty-six management traits, she found females saw themselves as more approachable, accessible and cooperative than their male counterparts. 
Kazlauskas (1993) specifically researched library faculty perceptions regarding department chairs' leadership practices. Surveying both nonsupervisory and supervisory academic librarians regarding their supervisors, she excluded only the library directors. The research was limited to institutions in one state university system.

Bailey (1987) highlighted the need for more research regarding the leadership in library/information services, which chairs as middle managers, may provide. Sullivan (1992) observed the transition of the focus of participants in the Association of Research Libraries' Office of Management Services Library Management Skills Institute from the 1980s to the 1990s. Participants' focus shifted from management for the sake of advancement and higher salaries, to the desire to be effective as leaders in their new role. With the myriad of changes taking place in academic libraries the role of the department head has been going through a time of transition (Bloss and Lanier, 1997). As we prepare for the transition of thousands of librarians to retirement (Curran, 2003), it is appropriate to look at the role our middle managers may play in the professional development, and vicariously the retention, within our ranks.

\section{RESEARCH QUESTION}

How the chair's role in enhancing the professional activities of faculty is perceived can have a profound effect upon the professional development of faculty. This is especially true of junior, not-yet-tenured faculty. Bensimon, et al. 
(2000) noted graduate programs (even doctoral programs) often do not do a good job of preparing or "socializing" students for the step into faculty positions and the accompanying requirements. Women and minorities are notably more vulnerable to this phenomenon. Beyond being a profession with a high percentage of women, Black \& Leysen (2002) pointed to the brevity of the program of study for the M.L.S., and the lack of requirements for a research thesis, as factors making academic librarians even less prepared for their faculty roles. If these new library faculty members perceive the chair's role as one of a leader in assisting them, but the assistance is not forthcoming, the lack of leadership may lead to unfavorable tenure and promotion decisions for the junior faculty.

As noted earlier, academic library middle managers and the librarians themselves, have in the past considered professional development an individual responsibility. Mitchell (1986) reported the teaching department chairs in her initial sample indicated they believed the broader role of faculty development was "the professional obligation of the faculty themselves." More recently, McNeil (2004) broke development into three forms: staff development, "an organizational responsibility"; professional development, "a personal responsibility"; and career development, "the responsibility of both the individual and the library organization".

To determine perceptions regarding the department chair's role in 
enhancing the professional activities of faculty as held by not-yet-tenured, library faculty the question formulated for this research was: From the perspective of not-yet-tenured, library faculty members, what are the methods department chairs should use in enhancing the professional activities of faculty?

\section{METHODS}

A survey instrument was developed which listed twenty-seven methods department chairs may use in enhancing the professional activities of faculty. For the purpose of this study "enhancing the professional activities of faculty" referred to activities, programs, and procedures which assist faculty in gaining knowledge, training, skills, attitudes, and insights that improve their ability to be more effective in their professional lives (Tucker, 1992, p. 267-8; Wilhite, 1987, p.6). The twenty-seven methods were derived from studying the works of Boden (1994), Creswell and Brown (1992), Mitchell (1986), and Wilhite (1987). All of these works used qualitative research methods. All except Boden were studies of department chairpersons' perceptions. Boden's grounded theory study was of library faculty.

The survey instrument was distributed to all not-yet-tenured library faculty members at a land grant university in the midwestern United States. This audience was chosen due to their meeting the criteria set out in the "Research Question" section and their accessibility to the researcher.

The survey instrument included demographic information regarding the 
respondents' gender, libraries department, years in the profession, years at the present institution, and educational level completed. Respondents were requested to rate each of the twenty-seven methods a department chair might use in enhancing the professional activities of faculty based on a five-point scale. On the scale " 1 " indicated the respondent felt the method was "unimportant," while a "5" indicated the method was "very important" (see Appendix A).

Each of the twenty-seven method statements was coded according to categories identified by Creswell (1991) as "practices chairs engage in in assisting faculty in their growth and development" (see Appendix B). This was done to assist any future comparisons of these methods for enhancing professional activities of non-teaching faculty to broader methods for enhancing faculty growth and development of teaching faculty.

The survey was distributed to nineteen not-yet-tenured faculty members along with a cover letter requesting the faculty member's assistance in the research. Respondents were given one week to complete and return the survey. Just prior to the deadline an electronic mail message was sent to all possible respondents, thanking them for their response and reminding those who had not yet returned the survey that they still could. This action did not result in any additional surveys being returned. Sixteen of the nineteen distributed surveys were returned for an $84 \%$ return rate. The return rate by department varied from $67 \%$ to $100 \%$ (see Appendix C). Other tables in Appendix C show the other 
demographic information collected.

\section{RESULTS}

The data were first analyzed to determine the perceived importance the junior library faculty placed on each of the twenty-seven methods chairs may use in enhancing the professional activities of faculty. Appendix D presents the rankings and mean scores of the items from the highest to the lowest ranked, or the items perceived as most important to least important. The category code is also listed for each statement. Five statements had means above four. The methods perceived as most important were, "Provide resources to support professional activities of faculty," "Foster a professional atmosphere, open to ideas and innovation, without fear of failure or punishment," "Provide ongoing feedback to faculty regarding their professional performance," "Acknowledge, compliment, and provide positive reinforcement for good performance and accomplishments," and "Act as an advocate for resources with the dean's office and higher administration." One method emerged prominently as perceived as least important in the role of the department chair in enhancing the professional activities of faculty. That method was "Spend time with faculty informally in social settings." The rating was only 1.6875 , with all other methods rated at least one full point higher. Two other methods were rated below three. They were, "Encourage faculty to collaborate with, or assist, the department head, or a senior faculty member, on a project," and "Provide regular meetings for groups of 
faculty to discuss ways to enhance faculty growth and development." The other nineteen statements received ratings between 3.0 and 3.94. The overall mean for all responses was 3.539 .

Next, an analysis of the range of scores assigned to each method was done. Four of the top five ranked statements had no scores of "1" assigned to them. In fact, for those four statements, a total of only two "2s" were assigned. The lowest ranked statement received no scores above " 3 ," and almost half the respondents, seven of sixteen, gave it the lowest rating of "1," or "unimportant." All but five of the other twenty-two statements received scores ranging from either "1" to "4," or "1" to "5." Four of those five other statements were in the top nine rated statements; however, they were subject to one outlier which gave a "1" rating, while the rest rated the method from "3" to "5."

\section{Category Codes}

In reviewing the category codes for each method statement, as it relates to the ranking of the statement, some interesting findings came to light. Four of five statements with category codes of "001," identifying method statements where chairs would be "helping faculty develop and refine skills," were rated near the bottom on importance. The four statements were in the bottom third of the rankings. The respondents in this research obviously see these methods as less important than many of the other methods chairs may use to enhance the professional activities of faculty. The means for the items, however, were 
between 3.0 and 3.3 indicating faculty in this research did feel the items were moderately important. One statement in this category code was ranked in the top ten. That method statement was "Lead by example -- provide a role model" and had a mean score of 3.75. So the non-teaching faculty involved in this research, split the category on the basis of the individual method identified.

Splitting the statements, related to particular category codes, into different levels of importance, was the general rule with the results of this survey. Category code "002," "helping faculty relate to the organizational environment," with nine statements, finds three in the top third of the rankings, two in the middle third, and the remaining four statements in the bottom third of the rankings. Taking a look at the statements themselves it seems the respondents perceive the chair's role more as one of an advocate promoting a professional atmosphere and encouraging and publicizing faculty activities. Less important are activities as an intermediary, or methods to promote interaction between colleagues.

Category code "004" for "relating to faculty personally" also shows a split in the rankings of the six method statements. Two are in the top third, three in the middle third, and the remaining statement is the lowest ranked item in the survey. Considering the statements in the top two-thirds with a mean of 3.3 or higher, we find the respondents desire a chair that is a good communicator. According to the statements the chair should give positive reinforcement, keep faculty informed, be available, be a good listener, and show an interest in each faculty member. An 
activity the faculty in this research did not consider part of the role of the chair was informal social interaction with faculty.

The "003" category code for "helping faculty in an administrative capacity" received more consistent rankings. All seven statements are in the top two-thirds of the rankings, with means of 3.4 or above. The respondents obviously see providing resources, time, and input regarding professional performance, goals, organizational expectations, and progress toward tenure and promotion, and sharing responsibilities, as important methods chairs should use in enhancing the professional activities of faculty.

\section{Relationship to Existing Literature}

The findings of this study were generally consistent with what was expected. Library faculty members, like their teaching counterparts, are most interested in growing professionally and obtaining tenure and promotion. Their perceptions of the role of the department chair are hopeful statements of a desire for support from the chairperson in obtaining those goals. Resources, academic freedom, feedback, positive reinforcement, supportive communication, and assistance are all high priorities as faculty look at actions they hope their department chair will undertake to help them enhance their professional activities.

Several activities chairs may undertake to enhance faculty members' professional activities are identified in the literature and were outlined earlier here. The respondents to this survey supported the importance of these functions 
of the chair as well. Most notably activities, noted in the literature for years, which respondents for this research ranked in the top third, were "encourages faculty to participate in conventions, conferences, professional associations, etc." (Smith, 1972), "commending achievement" (Moses, 1985), and "maintaining a spirit of inquiry and academic freedom" (McLaughlin et al., 1975). The statements on the survey corresponding to these were numbers seven, eight, and twenty-three.

The most interesting aspects of the results of this research project were the three lowest rated method statements. The existing literature suggests the chair should have a role in assisting faculty with collaborating with senior faculty, or with the chair, on research projects, proposal development, publications, and the like (Creswell and Brown, 1992; Mitchell, 1986, p. 136; Seagren et al., 1986; Wilhite, 1987, p. 93). Yet, this group of respondents gave that method of enhancing the professional activities of faculty a rating placing it twenty-fifth of the twenty-seven methods, and a mean noting the method as less than moderately important. Perhaps this is due simply to the perception that other methods are of higher importance or, as some of the literature has suggested; perhaps these library faculty members consider this sort of activity their own individual responsibility.

The twenty-sixth rated of the twenty-seven method statements involved providing regular meetings for faculty to discuss ways to enhance faculty growth 
and development. This relates to the concept of the department as a "community of scholars" (Seagren et al., 1986). Considering the context of the university libraries at the institution at the time of the survey, giving such a low rating to the possibility of more meetings may be understandable. The public services division was undergoing a multi-part analysis, while technical services were analyzing workflow issues, all in preparation for the Academic Program Review. Many meetings were being held and had been being held for several months. More meetings, no matter how desirable their purpose, may have been perceived as undesirable.

The lowest ranked method a chair might use to enhance the professional activities of faculty, "Spend time with faculty informally in social settings", received a mean score indicating the method was not even "slightly important." Some research on chairs' perceptions of their role have noted chairs perceive part of their role as handling social events for the department (Mitchell, 1986, p. 138) or informally spending time with faculty as part of an encouraging role (Creswell and Brown, 1992). Bensimon et al (2000, p. 49-50) noted how welcoming social gatherings, and just being individually introduced to colleagues, can be for new faculty. It seems the library faculty respondents to this survey perceived little need or desire for chairs to fulfill such a role.

\section{SUMMARY}

Much research exists regarding perceptions of the overall role of the 
department chair. Research has been done on academic, teaching department chairs from the perspectives of the chairs themselves, higher administrators, and faculty. More recently, research has been done on chairs' perceptions of their role in faculty growth and professional development. This research project sought to strike out in a new area in two ways: 1) the research addressed faculty perceptions of the chair's role in faculty development; and 2) the faculty members studied were in non-teaching departments in a university library setting. Also, the survey subjects were junior, not-yet-tenured, library faculty members. Because faculty development often includes a teaching component, the title for the role studied was changed to "enhancing the professional activities of faculty" and a definition developed for that role.

A survey instrument designed for the study included five questions of a demographic nature, and twenty-seven statements of methods department chairs may use in enhancing the professional activities of faculty. Respondents rated each statement on a five-point scale.

The respondents to the survey indicated most methods outlined in the qualitative research on chairs' perceptions of the chairperson's role in faculty development, are also considered by library faculty to be moderately to very important in enhancing their professional activities.

Thoughts and Recommendations

As academic libraries look toward the future and the transition to new 
generations of library professionals, recruitment, socialization, acculturation, retention, development, support, and continuing revitalization will remain important. Academic library department chairs will play an important role in just how smooth that transition will be. This research has shown junior, not-yettenured library faculty members believe their chairs have a role in enhancing their professional development activities.

Further research regarding library faculty/ academic librarians', academic library department chairs', and top academic library administrators' (deans or directors) perceptions of the department chair's role in professional development is needed. Perceptions of faculty beyond the junior, not-yet-tenured should be researched. Perceptions across other levels of post-secondary institutions, across different types and sizes of institutions and libraries, should be researched as well. Research regarding possible effects of differences in the professional librarian's status on the perceptions of the professional development role of the department chair should be undertaken. For academic library department chairs to function well in support of their faculty's development activities, they must have the support of the library administration. Determination of academic library administrators' views, as well as those of the chairs themselves, regarding appropriate activities of middle level managers' in support of their faculty will advance understanding between the groups.

Over the years library literature has contained several articles regarding 
mentoring. Articles regarding mentoring have focused on mentoring to develop leaders in the ranks (Cargill, 1989), chairs or higher administrators mentoring their supervisees (Fulton, 1990) or information from leaders on the mentors who impacted them (McNeer, 1988; Sheldon, 1991). More recently there has been a shift toward general articles, or sections of articles, on mentoring with a broader focus on supporting junior faculty, guiding career development, encouraging less experienced colleagues, advising down the tenure track, retaining competent librarians, and leaders will emerge (Keyse et al, 2003; Martorana et al, 2004; Mavrinac, 2005; Mosley, 2005; Tysick \& Babb, 2006).

While many have asserted the mentor should not be the mentee's supervisor, there are cases of success in opposition to that rule, including this author. In several cases recommendations for support of mentoring includes provision of funding, travel, and release time (Keyse et al). Often it is the chairperson who informs, encourages, or plans with the faculty member regarding the activity and approves, or recommends, such activities to the higher administration. This research survey included such actions, as well as others developed from the broad department chair literature, in the twenty-seven statements of methods department chairs may use in enhancing the professional activities of faculty.

Chairs of teaching departments have been accepted as in a position to assist their faculty's development. Perceptions of the chair's role from the 
faculty's, the chair's and higher administrators' viewpoints, and across a variety of institutional settings, have been the subject of research for decades. This research expanded the small amount of similar research that has begun regarding department chairs in academic libraries. The academic library department chairs must act as more than managers and supervisors of personnel. Library faculty, like their teaching department counterparts, should be able to view their chair as interested in the development of their faculty. The department chairs must step up and not leave their faculty to fend for themselves in these important matters. Rather, they should communicate expectations, actively mentor, and take a leadership role to support not only new faculty, but all faculty members in their department, and provide the best opportunity for their institutional success and continued professional growth throughout their careers. Professionals striving to meet the ever-changing information needs of their colleagues across the academic community deserve nothing less. 


\section{REFERENCES}

Association of College and Research Libraries Committee on the Status of Academic Librarians. (2001). Faculty status and collective bargaining statements: Final versions. College and Research Libraries News, 62(3), 304-306.

ALISE Library and Information Science Education Statistical Report (1991, 1996, 2000, 2003). Table II-8-a. Retrieved February 17, 2006 from the World Wide Web: http://ils.unc.edu/ALISE/2003/Students/Table\%20II-8-a.htm

Bailey, M. J. (1976, January). Some effects of faculty status on supervision in academic libraries. College and Research Libraries, 37, 48-52.

Bailey, M. J. (1978, September). Requirements for middle managerial positions. Special Libraries, 69, 323-331.

Bailey, M. J. (1981). Supervisory and middle managers in libraries. Metuchen, NJ: Scarecrow Press.

Bailey, M. J. (1987, September). Middle managers in libraries/information services. Library Administration and Management, 1, 139-142.

Bailey, M. J. \& Murphy, M. (1989). Management competencies of middle managers in large academic research libraries. Paper presented at the $5^{\text {th }}$ National Conference of the Association of College and Research Libraries. Cincinnati, $\mathrm{OH}$. (ERIC Document Reproduction Service No. ED 314 061)

Baldwin, R. G. (1990). Faculty career stages and implications for professional development. In J. H. Schuster, D. W. Wheeler, \& Associates, 
Enhancing faculty careers: Strategies for development and renewal (pp. 20-40). San Francisco: Jossey-Bass.

Bensimon, E. M., Ward, K. A. \& Sanders, K. (2000). The department chair's role in developing new faculty into teachers and scholars. Bolton, MA:

Anker.

Bergquist, W. H. \& Phillips, S. R. (1975). A handbook for faculty development (Volume 1). Washington, DC: Council for the Advancement of Small Colleges.

Black, W. K. \& Leysen, J. M. (2002). Fostering success: The socialization of entry-level librarians in ARL libraries. Journal of Library Administration, 36(4), 3-26.

Bland, C. \& Schmitz, C. C. (1988). Faculty vitality on review: Retrospect and prospect. Journal of Higher Education, 59(2), 190-224.

Bland, C. J., \& Schmitz, C. C. (1990a). An overview of research on faculty and institutional vitality. In J. H. Schuster, D. W. Wheeler , \& Associates, Enhancing faculty careers: Strategies for development and renewal (pp. 41-61). San Francisco: Jossey-Bass.

Bland, C. J., \& Schmitz, C. C. (1990b). A guide to the literature on faculty development. In J. H. Schuster, D. W. Wheeler, \& Associates, Enhancing faculty careers: Strategies for development and renewal (pp. 298-328). San Francisco: Jossey-Bass. 
Bloss, A. \& Lanier, D. (1997). The library department head in the context of matrix management and reengineering. College and Research Libraries, 58(6), 499-508.

Boden, D. W. R. (1994). A university libraries faculty perspective on the role of the department head in faculty performance: A grounded theory approach. Revised. (ERIC Document Reproduction Service No. ED 377 758).

Boice, R. (1992). The new faculty member: Supporting and fostering professional development. San Francisco: Jossey-Bass.

Boice, R. (2000). Advice for new faculty members: Nihil nimus. Boston: Allyn and Bacon.

Boice, R., Scepanski, J. M., Wilson, W. (1987). Librarians and faculty members: Coping with pressures to publish. College and Research Libraries, 48(6), 494-503.

Cargill, J. (1989). Developing library leaders: The role of mentorship. Library Administration and Management, 3(Winter), 12-15.

Carver, D. A. (2005). Should librarians get tenure? No, it can hamper their roles. (2005, September 30). The Chronicle of Higher Education, 52(6), B10. Retrieved February 17, 2006 from the World Wide Web: http://chronicle.com/free/v52/i06/06b01002.htm

Cary, S. (2001). Faculty rank, status, and tenure for librarians: Current trends. College and Research Libraries News, 62(5), 510-511, 520. 
Coats, L. T., Lovell, N. B., \& Franks, M. E. (1996). FIRO B: Analyzing community college department chairs' effectiveness. Paper presented at the Southeastern Association for Community College Research Conference, Panama City, FL. (ERIC Document Reproduction Service No. ED 406 999).

Cohen, W. D., Bleha, B., \& Olswang, S. G. (1981). Administrative roles and perceptions of governance in the community college. Community/Junior College Research Quarterly, 5, 303-321.

Comes, J. F. (1978/1979). Relationships between leadership behavior and goal attainment in selected academic libraries (Doctoral dissertation, Ball State University, 1978). Dissertation Abstracts International, 39 (10), 5782A (UMI No. 7905229).

Creswell, J. W. (1991). [Codes, categories, and illustrations: Practices chairs engage in in assisting faculty in their growth and development]. Unpublished raw data.

Creswell, J. W. \& Brown, M. L. (1992). How chairpersons enhance faculty research: A grounded theory study. The Review of Higher Education, 16(1), 41-62.

Creswell, J. W., Wheeler, D. W., Seagren, A. T., Egly, N. J., \& Beyer, K. D. (1990). The academic chairperson's handbook. Lincoln, NE: University of Nebraska Press.

Curran, W. M. (2003). Succession: The next ones at bat. College \& 
Research Libraries, 64(2), 134-140.

Curtis, J. W. (2004). American Association of University Professors. Faculty Salary and Faculty Distribution Fact Sheet 2003-04. Retrieved February 17, 2006 from the World Wide Web: http://www.aaup.org/Issues/WomeninHE/sal\&distribution.htm

Daly, F. \& Townsend, B. K. (1992). Faculty perceptions of the department chair's role in facilitating tenure acquisition. Paper presented at the annual meeting of the Association for the Study of Higher Education, Minneapolis, MN. (ERIC Document Reproduction Service No. ED 352 912)

Daly, F. \& Townsend, B. K. (1994). The chair's role in tenure acquisition. The NEA Higher Education Journal: Thought and Action, 9(2), 125-145.

Eble, K. E. (1986). Chairpersons and faculty development. The Department Adviser, 1(4), 1-5.

Eble, K. E. (1990). Chairpersons and faculty development. In J. B. Bennett \& D. J. Figuli (Eds.), Enhancing departmental leadership: The roles of the chairperson. (pp. 99-106). New York: American Council on Education.

Eble, K. E. \& McKeachie, W. J. (1985). Improving undergraduate education through faculty development: An analysis of effective programs and practices. San Francisco: Jossey-Bass.

Evans, G. E. \& Ward, P. L. (2003). Beyond the basics: The management guide for library and information professionals. New York: Neal-Schuman. 
Falk, G. (1979). The academic department chairmanship and role conflict. Improving College and University Teaching, 27(2), 79-86.

Fulton, T. L. (1990). Mentor meets Telemachus: The role of the department head in orienting and inducting the beginning reference librarian. In B. Katz (Ed.), Continuing education of reference librarians. The reference librarian, no. 30, (pp. 257-273). New York: The Haworth Press.

Gaff, J. G. (1975). Toward faculty renewal: Advances in faculty, instructional, and organizational development. San Francisco: Jossey-Bass.

Giesecke, J. (2001). Practical strategies for library managers. Chicago: American Library Association.

Giesecke, J. (Ed.). (1992). Practical help for new supervisors [2 $2^{\text {nd }}$ ed.]. Chicago: American Library Association.

Giesecke, J. (Ed.). (1997). Practical help for new supervisors $\left(3^{\text {rd }}\right.$ ed.). Chicago: American Library Association.

Giesecke, J. \& McNeil, B. (2005). Fundamentals of library supervision (ALA fundamentals series). Chicago: American Library Association.

Gmelch, W. H. \& Miskin, V. D. (1993)._Leadership skills for department chairs. Bolton, MA: Anker Publishing.

Gmelch, W. H. \& Miskin, V. D. (1995). Survival skills for scholars: Vol. 15. Chairing an academic department. Thousand Oaks, CA: Sage Publications. 
Gordon, R. S. (2005). The accidental library manager. Medford, N.J.: Information Today.

Gordon, B. G., Stockard, J. W., Jr., \& Williford, H. N. (1991). The perceived and expected roles and responsibilities of departmental chairpersons in schools of education as determined by teaching faculty. Education, 112(2), 176182.

Group for Human Development in Higher Education. (1974). Faculty development in a time of retrenchment. New Rochelle, NY: Change.

Hecht, I. W. D., Higgerson, M. L., Gmelch, W. H., \& Tucker, A. (1999). The department chair as academic leader (Oryx Press series on higher education). Phoenix, AZ: American Council on Education.

Heimler, C. H. (1967). The college departmental chairman. Educational Record, 48, 158-163.

Hill, J. S. (2005). Constant vigilance, babelfish, and foot surgery: Perspectives on faculty status and tenure for academic librarians. portal: Libraries and the Academy, 5(1), 7-22.

Hirokawa, R. Y., Barge, J. K., Becker, S. L., \& Sutherland, J. L. (1989). The department chair as responsible academic leader: A competency-based perspective. ACA Bulletin, 67, 8-19.

Jeffrey, R. C. (1985, April). A dean interprets the roles and powers of an ideal chair. Association for Communication Administration Bulletin, 52, 15-16. 
Jennerich, E. J. (1981). Competencies for department chairpersons: Myths and realities. Liberal Education, 67(1), 46-70.

Jones, D. R. \& Holdaway, E. A. (1995). Expectations held for department heads in postsecondary institutions. The Alberta Journal of Educational Research, 41(2), 188-212.

Kazlauskas, D. W. (1993). Leadership practices and employee job satisfaction in the academic libraries of the state university system of Florida (Doctoral dissertation, University of Florida, 1993). Dissertation Abstracts International, 55 (10), 3053A. (UMI No. 9505669).

Kenny, S. S. (1982). Three views of the chair: Perspectives of the department members, the dean, and the chairperson. ADE Bulletin, 73(Winter), $33-37$.

Keyse, D., Kraemer, E. W., \& Voelck, J. (2003). Mentoring untenured librarians: All it takes is a little Un-TLC. College \& Research Libraries News, 64(6), 378-380.

Knight, W. H. \& Holen, M. C. (1985). Leadership and the perceived effectiveness of department chairpersons. Journal of Higher Education, 56(6), 677-690.

Knight, P. T. \& Trowler, P. R. (2001). Departmental leadership in higher education. Buckingham, England: Society for Research into Higher Education and Open University Press. 
Kremer-Hayon, L. \& Avi-Itzhak, T. E. (1986). Roles of academic department chairpersons at the university level: Perceptions and satisfaction. Higher Education, 15, 105-112.

Kroll, S. (1994)._Academic status: Statements and resources $\left(2^{\text {nd }}\right.$ ed.). Chicago: Association of College and Research Libraries, American Library Association.

Krompart, J. (1994). A bibliographic essay on faculty status for academic librarians. In S. Kroll (Ed.), Academic status: Statements and resources (pp.2938) ( $2^{\text {nd }}$ ed.). Chicago: Association of College and Research Libraries, American Library Association.

Kyrillidou, M., \& Young, M. (2005a). ARL Annual Salary Survey 200405. Washington, DC: Association of Research Libraries. Retrieved February 17, 2006 from the World Wide Web: http://www.arl.org/stats/pubpdf/ss04.pdf

Kyrillidou, M., \& Young, M. (2005b). ARL Statistics 2003-04: A Compilation of Statistics from the One Hundred and Twenty-Three Members of the Association of Research Libraries. Washington, DC: Association of Research Libraries. Retrieved February 17, 2006 from the World Wide Web: http://www.arl.org/stats/pubpdf/arlstat04.pdf

Leaming, D. R. (1998). Academic leadership: A practical guide to chairing the department. Bolton, MA: Anker.

Lee, D. E. (1985). Department chairpersons' perceptions of the role in 
three institutions. Perceptual and Motor Skills, 61, 23-49.

Leysen, J. M. \& Black, W. K. (1998). Peer review in Carnegie Research libraries. College \& Research Libraries, 59(6), 512-522.

Licata, C. M. (2000). Post-tenure review. In A. F. Lucas \& Associates, Leading academic change : Essential roles for department chairs (pp. 107-137) (The Jossey-Bass higher education series). San Francisco : Jossey-Bass.

Lowry, C. B. (1993). Research notes: The status of faculty status for academic librarians: A twenty-year perspective. College \& Research Libraries, $54(2), 163-172$.

Lucas, A. F. \& Associates. (2000). Leading academic change : Essential roles for department chairs (The Jossey-Bass higher education series). San Francisco : Jossey-Bass.

Martorana, J., Schroeder, E., Snowhill, L., \& Duda, A. L. (2004). A focus on mentorship in career development. Library Administration \& Management, 18(4), 198-202.

Mavrinac, M. A. (2005). Transformational leadership: Peer mentoring as a values-based learning process. portal: Libraries and the Academy, 5(3), 391-404.

McAnally, A. M. (1975). Status of the university librarian in the academic community. In Association of College and Research Libraries Committee on the Status of Academic Librarians, Faculty status for academic librarians: A history and policy statements (pp. 1-30). Chicago: American Library Association. 
McKeachie, W. J. (1990). Tactics and strategies for faculty development. In J. B. Bennett \& D. J. Figuli (Eds.), Enhancing departmental leadership: The roles of the chairperson. (pp. 107-114). New York: American Council on Education.

McLaughlin, G. W., Montgomery, J. R., \& Malpass, L. F. (1975). Selected characteristics, roles, goals, and satisfactions of department chairmen in state and land-grant institutions. Research in Higher Education, 3, 243-259.

McNeer, E. J. (1988). The mentoring influence in the careers of women ARL directors. Journal of Library Administration, 9(2), 23-33.

McNeil, B. (2004). Managing work performance and career development. In J. Simmons-Welburn \& B. McNeil (Eds.), Human resource management in today's academic library: Meeting challenges and creating opportunities (Libraries Unlimited library management collection). Westport, CT: Libraries Unlimited.

Mech, T. \& McCabe, G. B. (Eds.). (1998). Leadership and academic librarians (Greenwood library management collection).Westport, CT: Greenwood.

Miles, B. W. (1983). Trials and tribulations of the academic chair. Journal of the College and University Personnel Association, 34(4), 11-15.

Mitchell, M. B. (1986). Department chairperson management strategies: Enhancing faculty performance and work satisfaction. (Doctoral dissertation, 
University of Nebraska, 1986). Dissertation Abstracts International, 47 (11), 3995A (UMI No. 8706240).

Mitchell, E. S. (1989). The library leadership project: A test of leadership effectiveness in academic libraries. In G. B. McCabe \& B. Kreissman (Eds.), Advances in library administration and organization (Vol. 8, pp. 25-38). Greenwich, Ct: JAI Press.

Moses, I. (1985). The role of head of department in the pursuit of excellence. Higher Education, 14, 337-354.

Mosley, P. A. (2005). Mentoring gen x managers: Tomorrow’s library leadership is already here. Library Administration \& Management, 19(4), 185192.

Moxley, J. M. \& Olson, G. A. (1990). The English chair: Scholar or bureaucrat? The NEA Higher Education Journal: Thought and Action, 6(1), 5158.

Murray-Rust, C. (2005). Should librarians get tenure? Yes, it's crucial to their jobs. (2005, September 30). The Chronicle of Higher Education, 52(6), B10. Retrieved February 17, 2006 from the World Wide Web: http://chronicle.com/free/v52/i06/06b01001.htm

Neumann, L. \& Neumann, Y. (1983). Faculty perceptions of deans' and department chairpersons' management functions. Higher Education, 12, 205-214.

Olive, J. F., III (1991). Leadership styles of selected academic library 
department heads as perceived by self and subordinates. (Doctoral dissertation, University of Alabama, 1991). Dissertation Abstracts International, 52 (7), 2430A (UMI No. 9201175).

Person, R. J. (1980). Middle managers in academic and public libraries: Managerial role concepts. (Doctoral dissertation, University of Michigan, 1980). Dissertation Abstracts International, 41 (5), 1820A (UMI No. 8025745).

Plate, K. H. (1970). Management personnel in libraries: A theoretical model for analysis. Rockaway, NJ: American Faculty Press.

Pugh, L. (2005). Managing 21 st century libraries. Lanham, MD: Scarecrow.

Roach, J. H. L. (1976). The academic department chairperson: Functions and responsibilities. Educational Record, 57(1), 13-23.

Ruess, D. E. (2004). Faculty and professional appointments of academic librarians: Expanding the options for choice. portal: Libraries and the Academy, $4(1), 75-84$.

Scott, J. H. (1990). Role of community college department chairs in faculty development. Community College Review, 18(3), 12-16.

Seagren, A. T., Creswell, J. W., \& Wheeler, D. W. (1993). The department chair: New roles, responsibilities and challenges. (ASHE-ERIC Higher Education Report: No. 1.) Washington, DC: The George Washington University, School of Education and Human Development. 
Seagren, A. T., Wheeler, D. W., Creswell, J. W., Miller, M. T., \& VanHorn-Grassmeyer, K. (1994). Academic leadership in community colleges. Lincoln, NE: University of Nebraska Press.

Seagren, A. T., Wheeler, D. W., Mitchell, M. B., \& Creswell, J. W. (1986). Perception of chairpersons and faculty concerning roles descriptors and activities important for faculty development and departmental vitality. (ERIC Document Reproduction Service No. ED 276 387).

Sheldon, B.E. (1991). Leaders in libraries: Styles and strategies for success. Chicago: American Library Association.

Siever, R. G., Loomis, R. J., \& Neidt, C. O. (1972). Role perceptions of department chairmen in two land grant universities. The Journal of Educational Research, 65(9), 405-410.

Simmons-Welburn, J. \& McNeil, B. (Eds.). (2004). Human resource management in today's academic library: Meeting challenges and creating opportunities (Libraries Unlimited library management collection). Westport, CT: Libraries Unlimited.

Smart, J. C. (1976). Duties performed by department chairmen in Holland's model environments. Journal of Educational Psychology, 68(2), 194204.

Smith, A. B. (1972). Department chairmen: Neither fish nor fowl. Junior College Journal, 42(6), 40-43. 
Sorcinelli, M. D. (1990). Development of new faculty. The Department Chair, 1(2), 9.

Sparks, R. (1976). Library management: Consideration and structure. Journal of Academic Librarianship, 2(2), 66-71.

Stone, E. W. (1969). Factors related to the professional development of librarians. Metuchen, NJ: Scarecrow.

Sullivan, M. (1992). The changing role of the middle manager in research libraries. Library Trends, 41(2), 269-281.

Thompson, H. L. (1990). The department chairperson: An academic leader. The Department Chair, 1(2), 16-17, 19.

Tucker, A. (1992). Chairing the academic department: Leadership among peers (3rd ed.). New York: American Council on Education.

Tysick, C. \& Babb, N. (2006). Perspectives on... Writing support for junior faculty librarians: A case study. The Journal of Academic Librarianship, 32(1), 94-100.

Voelck, J. (2003). Directive and connective: Gender-based differences in the management styles of academic library managers. portal: Libraries and the Academy, 3(3), 393-418.

Watson, R. E. L. (1979). The role of the department head or chairman: Discipline, sex and nationality as factors influencing faculty opinion. The Canadian Journal of Higher Education, 9(3), 19-28. 
Watson, R. E. L. (1986). The role of the department chair: A replication and extension. The Canadian Journal of Higher Education, 16(1), 13-23.

Weinberg, S. S. (1984). The perceived responsibilities of the departmental chairperson: A note of a preliminary study. Higher Education, 13, 301-303.

Wheeler, D. W. (1992). The role of the chairperson in support of junior faculty. In Sorcinelli, M. D. \& Austin, A. E. (Eds.), Developing new and junior faculty. New Directions for Teaching and Learning, no. 50 (pp. 87-96). San Francisco: Jossey-Bass.

Whitt, E. J. (1991). "Hit the ground running": Experiences of new faculty in a school of education. The Review of Higher Education, 14(2), 177-197.

Wilhite, M. S. (1987). Department chairperson behaviors: Enhancing the growth and development of faculty (Doctoral dissertation, University of Nebraska-Lincoln, 1987). Dissertation Abstracts International, 48 (7), 1620A (UMI No. 8722425).

Wilhite, M. S. (1990). Practices used by effective department chairs to enhance growth and development of faculty. NACTA Journal, 34(2), 17-20.

Wittenbach, S. A., Bordeianu, S. M. \& Wycisk, K. (1992). Management preparation and training of department heads in ARL libraries. College \& Research Libraries, 53(4): 319-30. 


\section{Appendix A}

Survey of Faculty Perceptions

of the Role of the Department Head

in Enhancing the Professional Activities of Faculty

\section{Demographic Information:}

Please mark the correct answer with an " $X$ ".

a. Your gender: (1) Female

(2) Male

b. Your department:

(1) Reference Services

(2) Branch Services

(3) General Services

(4) Cataloging

(5) Serials Cataloging

c. Years in the library profession:

(1) $1-3$

(2) $4-5$

(3) $6-10$

(4) $11-15$

(5) $16+$

d. Time at Institution:

(1) Up to 1 year

(2) 1 to 2 years

(3) 2 to 3 years

(4) 3 to 4 years

(5) 4 to 5 years

(6) More than 5 years

e. Education completed:

(1) MLS

(2) MLS and additional coursework

(3) MLS and second Masters degree

(4) MLS, $2^{\text {nd }}$ Masters and additional coursework 


\section{Survey Statements:}

For the purpose of this study, "enhancing the professional activities of faculty" refers to activities, programs, and procedures which assist faculty in gaining knowledge, training, skills, attitudes, and insights that improve their ability to be more effective in their professional lives.

Listed below are some methods a department chair may use in enhancing the professional activities of faculty. Please read each method and circle the number reflecting how important you believe that method is in enhancing the professional activities of faculty.

Please rate the items based on the following five point scale:

\section{1 - Unimportant $\quad 2$-Slightly Important $\quad 3$ - Moderately Important 4 - Important 5 - Very Important}

1. Keep faculty informed of opportunities to participate in professional activities. (004)

2. Maintain an "open door policy" so faculty can speak with her/him at any time. (004)

3. Monitor faculty progress toward tenure and promotion. (0031)

$\begin{array}{lllll}1 & 2 & 3 & 4 & 5\end{array}$

4. Provide ongoing feedback to faculty regarding their professional performance. (0031)

$\begin{array}{lllll}1 & 2 & 3 & 4 & 5\end{array}$

5. Act as an intermediary for the faculty with the dean's office and higher administration. (002)

$\begin{array}{lllll}1 & 2 & 3 & 4 & 5\end{array}$

6. Provide resources to support professional activities of faculty (funding, travel, release time, staff support, etc.) (0034) 


\section{Scale: $\quad 1$ - Unimportant to 5 - Very Important}

7. Encourage participation in professional peer groups at the local, state, regional, national level (committees, conferences, publishing, research, etc.) (002)

8. Acknowledge, compliment, and provide positive reinforcement for good performance and accomplishments. (004)

$\begin{array}{lllll}1 & 2 & 3 & 4 & 5\end{array}$

Publicize faculty accomplishments

to administrators, fellow faculty, and $\quad \begin{array}{lllllll}1 & 2 & 3 & 4 & 5\end{array}$ peer groups. (002)

10. Lead by example - provide a role model. $(001)$

$\begin{array}{lllll}1 & 2 & 3 & 4 & 5\end{array}$

11. Delegate responsibility for projects to faculty to provide growth through more and more responsible activities. (003)

$\begin{array}{lllll}1 & 2 & 3 & 4 & 5\end{array}$

12. Act as an advocate by assisting faculty in getting involved in professional organizations and activities (name dropping, nominating, recommending, etc.) (002) $\quad \begin{array}{llllll}1 & 2 & 3 & 4 & 5\end{array}$

13. Share advice, wisdom, experience, and expertise regarding carrying out professional activities. (001)

$\begin{array}{lllll}1 & 2 & 3 & 4 & 5\end{array}$

14. Communicate the professional expectations of the organization (department, unit, institution) to the faculty. (003)

$\begin{array}{lllll}1 & 2 & 3 & 4 & 5\end{array}$




\section{Scale: $\quad 1$ - Unimportant to 5 - Very Important}

15. Help relieve pressures and stress

by reducing workload to provide time for faculty to initiate research and serve on visible committees. (0033) $\quad 1 \quad \begin{array}{llllll}2 & 3 & 4 & 5\end{array}$

16. Encourage faculty to collaborate with, or assist, the department head, or a senior faculty member, on a project. (002)

$\begin{array}{lllll}1 & 2 & 3 & 4 & 5\end{array}$

17. Assist faculty, in setting realistic, professional goals and priorities. (0031) $\quad \begin{array}{llllll}1 & 2 & 3 & 4 & 5\end{array}$

18. Refer faculty to workshops, centers, or training courses for improving, or providing support for, their capabilities for growth and development. (001)

$\begin{array}{lllll}1 & 2 & 3 & 4 & 5\end{array}$

19. Show a personal, individual interest in faculty member's growth and development activities. (004)

$\begin{array}{lllll}1 & 2 & 3 & 4 & 5\end{array}$

20. Provide regular meetings for groups of faculty to discuss ways to enhance faculty growth and development. (002) $\quad \begin{array}{llllll}1 & 2 & 3 & 4 & 5\end{array}$

21. Encourage faculty participation in campuswide activities and committees. (002)

$\begin{array}{lllll}1 & 2 & 3 & 4 & 5\end{array}$

22. Be a good listener. (004)

$\begin{array}{lllll}1 & 2 & 3 & 4 & 5\end{array}$

23. Foster a professional atmosphere, open to ideas and innovation without fear of failure or punishment. (002)

$\begin{array}{lllll}1 & 2 & 3 & 4 & 5\end{array}$

24. Act as an advocate for resources with the dean's office and higher administration. (002)

$\begin{array}{lllll}1 & 2 & 3 & 4 & 5\end{array}$




\section{Scale: $\quad 1$ - Unimportant to 5 - Very Important}

25. Help faculty to identify an area $\begin{array}{llllll}\text { of expertise. (001) } & 1 & 2 & 3 & 4 & 5\end{array}$

26. Spend time with faculty informally

$\begin{array}{lllllll}\text { In social settings. (004) } & 1 & 2 & 3 & 4 & 5\end{array}$

27. Support in-house staff development activities (instruction, training,

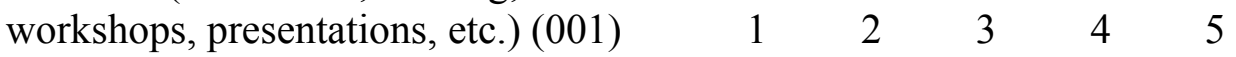

Thank You for completing this survey. Please fold it with the address out, staple it, and place it in the Libraries delivery.

Remember to return the completed survey by the date requested.

THANK YOU! 


\section{Appendix B}

Content Analysis Project

\section{Findings}

Categories

Codes, Categories, and Illustrations - Practices Chairs Engage in in Assisting Faculty in Their Growth and Development

001 Helping faculty develop and refine skills.

-in teaching (modeling, mentoring, critiquing teaching)

-in research (modeling, help choose areas, create teams, specialities)

-through staff development activities (in-house training, speakers, meetings, attend workshops)

002 Helping faculty relate to the organizational environment

- Advocate and promote the needs of faculty: externally, enhance faculty leadership (national visibility, professional associations, off campus networks) and internally, with individuals on campus, mediate for faculty with deans

- the interpersonal environment (faculty to faculty, faculty to staff)

- the departmental environment (atmosphere, openness, friendliness)

003 Helping faculty in an administrative capacity

0031 - Evaluating faculty performance (related to the department and institution - set goals, prioritize goals; related to the individual goal planning, student evaluations, annual appraisals, feedback; related to faculty careers - promotion and tenure)

0032 - Planning the long-range needs of the department: departmental/ institutional planning -goal setting, evaluation, prioritization; individual planning (goal setting, evaluation)

0033 - Schedule adjustments in assignments (released time workloads and assignments)

0034 - Providing material and financial resources (funds - travel, secretarial assistance, in-house, outside); equipment (laboratory, computers, materials) information (grants opportunity flyers, journals) 


\section{Appendix C}

$\underline{\text { Table C - } 1 \quad \underline{\text { Return rate by Department }}}$

Department

Total distributed

\# of respondents

Percentage

$\begin{array}{rllll}\mathrm{A} & \mathrm{B} & \mathrm{C} & \mathrm{D} & \mathrm{E} \\ 8 & 3 & 2 & 4 & 2 \\ 7 & 2 & 2 & 3 & 2 \\ 87.5 & 66.7 & 100 & 75 & 100\end{array}$

$\underline{\text { Table C - } 2}$ Gender of Respondents

Gender

Males

Females

\# of respondents

6

10

$\underline{\text { Table } \mathrm{C}-3} \underline{\text { Years in the Profession }}$

Years in Profession $\begin{array}{lllll}1-3 & 4-5 & 6-10 & 11-15 & 16+\end{array}$

\# of respondents

$\begin{array}{ccccc}1-3 & 4-5 & 6-10 & 11-15 & 16+ \\ 5 & 2 & 2 & 4 & 3\end{array}$

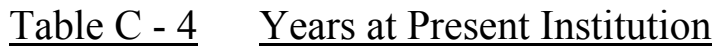

Years at Institution

$\begin{array}{cccccc}0-1 & 1-2 & 2-3 & 3-4 & 4-5 & 5+ \\ 2 & 3 & 4 & 4 & 1 & 2\end{array}$

\# of respondents

$\underline{\text { Table C - } 5}$ Educational Level of Respondents

Education MLS MLS+ 2nd Masters 2nd Masters+

\# of respondents

29

3 


\section{Appendix D}

$\underline{\text { Rank }} \underline{\text { Statement }}$

1 Provide resources to support professional activities of faculty

2 Foster a professional atmosphere, open to ideas and innovation without fear of failure or punishment.

0031

4a Acknowledge, compliment, and provide positive reinforcement for good performance and accomplishments.

004

4b Act as an advocate for resources with the dean's office and higher administration.

002

6a Encourage participation in professional peer groups at the local, state, regional, national level.

002

6b Help relieve pressures and stress by reducing workload to provide time for faculty to initiate research and serve on visible committees.

3.9375

0033

8 Monitor faculty progress toware tenure and promotion

0031

$9 \quad$ Keep faculty informed of opportunities to participate in professional activities.

004

10a Lead by example -- provide a role model.

3.75

001

10b Communicate the professional expectations of the organization to the faculty. 
12a Delegate responsibility for projects to faculty to provide growth through more and more responsible activities.

12b Act as an advocate by assisting faculty in getting involved in professional organizations and activities.

14a Maintain an "open door policy" so faculty can speak with her/him at any time.

16 Publicize faculty accomplishments to administrators, fellow faculty, and peer groups.

17 Assist faculty in setting realistic, professional goals and priorities.

18 Show a personal, individual interest in faculty member's growth and development activities.

19a Act as an intermediary for the faculty with the dean's office and higher administration.

19b Share advice, wisdom, experience, and expertise regarding carrying out professional activities.

19c Encourage faculty participation in campus-wide activities and committees.

22 Support in-house staff development activities.

23a Refer faculty to workshops, centers, or training courses for improving, or providing support for, their capability for growth and development. 
$\underline{\text { Rank }} \underline{\text { Statement }}$

Mean Category

$\underline{\text { Score }}$

Code

23b Help faculty to identify an area of expertise. $\quad 3.0625 \quad 001$

25 Encourage faculty to collaborate with, or assist, the department head, or a senior faculty member, on a project.

$2.9375 \quad 002$

26 Provide regular meetings for groups of faculty to discuss ways to enhance faculty growth and development.

002

27 Spend time with faculty informally in social settings.

$1.6875 \quad 004$ 